\title{
金型技術の進化* \\ Recent Progress of Die and Mold Technology
}

\section{中川威雄 \\ Takeo NAKAGAWA}

\section{1. 金型をとりまく環境}

21 世紀は地球環境の時代であるといわれてきたが, 資 源やエネルギーと食料の不足も深刻になることに間違いは ない.これらの解決のための技術の開発と社会システムの 変化が人類共通の課題としてその解決が求められている. しかしいかに精神生活を重視し無駄を省いてスリムな人間 社会を目指したとしても, 豊かな生活を希求する限り物質 文明に頼らざるを得ない面がある。物質文明の荷い手の主 役は機械製品であり，その製品を構成する機械部品はそれ が多量に生産される限り，金型を使った成形法が主たる製 造手段となる。その意味でものづくりの主役である機械産 業が存在する以上, 金型産業は不可欠なものである。同時 にその国の機械産業が衰退すれば, 金型産業は消滅し金型 技術の進歩も止まる。

順調に発展してきた日本の金型産業の成長は, 1990 年 のバブル期でピークを打ち, その後成長は止まり一進一退 を繰返してきた。このような状況下で特に零細下請企業が 多い金型産業では，製造業が衰退することによる経営危機 に遭遇する企業の廃業も多くなっている，天然資源のそし い日本は輸出産業に依存しているが, 輸出の $80 \%$ は機械 産業製品であるといわれており，この産業の衰退は日本の 豊かさが維持できないことを意味する。今や日本の最重要 の機械産業となった自動車製造はそれこそ金型による成形 機械部品の塊である。電機産業が衰退し, かといって工作 機械のように輸出に頼ることのできない生産財であるた め, 世界の勝ち組となっている国内自動車産業を頼みの綱 として生き残っているのが実情である.

\section{2. 金型技術は熟練手作業から IT 化へ}

金型は成形加工の道具であり, 成形機等の生産設備とそ れを使いこなす成形技術とともに発展してきた。金型製造 は成形ツールの母型であるため, 耐久性のある硬い金型材 料を複雑形状に加工し, しかもその寸法は高精度で表面の

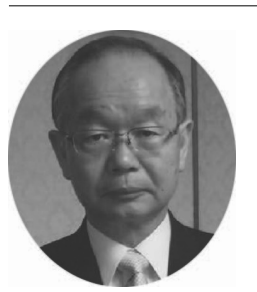

*原稿受付 平成 20 年 9 月 22 日

*正 会 員 ファインテック株式会社（東京都大 田区東糀谷 4-9-7) 中川威雄

1967 年東京大学大学院工学研究科精密機械工学 博士課程修了. 工学博士. 東京大学生産技術研 究所教授, 理化学研究所研究基盤技術部長を経 て, 東京大学名誉教授, 理化学研究所顧問. 2000 年にファインテック社を起業. 専門は生産 加工. 著書に「金型がわかる本」など.
滑らかさが要求される. 加工技術面からみるともっとも高 度な機械部品で構成されている一種の精密装置であり, 使 用される金型材も表面処理も最も高級な技術が惜しみなく 採用されている。しかも実際の金型づくりでは一品生産で 失敗は許されない. したがって金型技術は材料, 設計, 加 工, 制御, 生産システムに至るまで, 周辺で開発された実 に多くの新技術を取り込みながらハイテクと蓄積ノウハウ を駆使する産業となっている.

その中で過去 20 年にわたる金型の製造技術の変遷をみ ると, IT の導入による技術革新と自動化が進んだことが 最も大きな変化である. CAD や CAD/CAM が必需品と して急激に町工場に至るまで普及してきた。何といっても 機械部品の設計図面が, 3D CAD にとって替わった影響は 大きく, その設計データに基づいて金型設計も CAD 化 し, さらに加工も $\mathrm{M} / \mathrm{C}$ を使った $\mathrm{NC}$ 加工となり, それに 応じて無人加工や 3 次元測定器を使った金型自動計測も普 及した.さらにこれらを実現するための金型加工機や測定 器も高精度・高速化・自動化が進んだ。これらのIT 化の 影響は非常に大きなもので, 金型工場の姿を一昔前の労働 集約型産業から情報処理産業と大きく変えてしまったが, それらの高度化はまだ進行形といえる。

金型製造においては，加工技術が進化したこともあって 金型設計がより重要となっている，金型によるトラブルの 主なる原因は, 成形におけるノウハウのほとんどすべてが 金型設計に含まれていることから，金型が適切に設計され ていないことによって生ずる。この分野にも IT の CAE 技術は大きく貢献しつつある. 事前に成形時の材料挙動が シミュレーションされ，かなり正確に予測されるようにな った. これは溶融素材を流動させ成形する鋳造, ダイカス 卜, 樹脂成形から, 固体のまま変形させる鍛造やプレス加 工に至るまで，それぞれに応じたCAE プログラムが開発 され, 解析の速度も精度もさらに解析ノウハウも大幅に向 上し，今ではかなり広く活用されるようになった。もっと もシミュレーションは与えられた条件での成形結果を予測 するもので，トラブル発生の対策方法は，成形や金型を熟 知した人の判断に頼ることは言うまでもない.

\section{3. 少量生産時代のリードタイム短縮}

ほとんどのものづくり技術の進展は, 需要業界の強い二 ーズによって開発され現実の形に現れたものであることが 多い. 工業製品における新製品の開発競争はこのところ先 進工業国でますます激しいものとなり，特に日本はその先 
頭を走っている。その結果として，頻繁にモデルチェンジ が繰返され，そのたびに新技術が取り入れられるものの, 製品寿命は短くなり金型づくりにはリードタイム短縮が要 求される。同時に多品種少量生産が当たり前となり, 金型 需要は増大したものの, 金型製造の短納期とコスト削減が 強く求められ，それに対応する金型製造技術も次々と生ま れ採用されてきているが，前述のIT 化技術の多くは，リ ードタイム短縮効果も兼ね備えている.

さらに量産用金型製造に取り掛かる前に，多くの場合試 作品づくりがありこの過程での時間短縮も求められてい た. 製品設計後の機能シミュレーションやCGによるチェ ック技術も進んだが，試作品による実物評価に優るものは 存在しない。この分野に新しく登場したのが積層造形法で ある。この方法は初期のころは形状確認がせいぜいであっ たものが，材料改良による品質向上や精度と速度が向上し て，ラピッドプロとタイピングとも呼ばれるように試作品 として耐えられるものが多くなった。この技術の登場で 3DCAD の普及と相まって, 試作品製造の時間は劇的に短 縮されている。

このように，試作・金型設計 · 金型加工 · 検査も IT 化 した自動化が進行すると同時に, IT 化に基づいて各工程 の進行状況が一元化されることによりコンカレントエンジ ニアリンやリバースエンジニアリングなど最新の生産シス テムが効率よく採用される状況となった．しかし金型の完 成には最後の調整と仕上げ作業が残っている。ささに実際 に金型を取り付けて成形を行う段階では，成形機の機種ご との差や癖があって，部品生産の開始には熟成のために結 構多くの時間を費やすことも多い.これに対し最後の調整 作業までもなくしてしまおうという動きがあるが，これら は成形機と一体になって開発すべき技術である。成形機で いえば加圧機構にサーボモー夕駆動が一般化し, 成形機側 の調整の自由度は向上した。しかし最後のところはやはり 熟練のノウハウが重要であり, その重要性の高い金型は残 っている。また少量生産では金型の交換頻度は多くなるた め，交換しやすい金型も工夫されている.

\section{4. グローバル生産時代の日本の金型}

機械製造業のグローバル化は, 当初自動化の困難な機械 部品の組み立てから始まり, 次いで大量生産用機械部品の 製造に移った。量産部品の製造は金型を使う成形加工が主 体であり，金属材料の鋳造，樹脂材料の射出成形，金属材 料のプレス加工，さらに二次加工の工作機による加工が日 本から出ていった。当初は成形用設備とともに金型は輸出 されていたが，金型は使用途中で破損・修理もあり，現地 調達の要望が強く次第に現地生産化され，同時に金型用工 作機械の輸出が増えだした。成形用材料や金型用材料で高 級材は日本から輸出され現地生産を促進することに貢献し た。このように金型生産を含め文字通りのグローバル生産 が進行しつつあり，日本国内の製造業の空洞化が始まって いる。これに対し日本の製造業は金型のコストダウン，成
形の高速化，歩留まりの向上，金型の迅速交換による成形 機の効率利用, 多種少量生産下での自動化・省力化を目指 し，幾つかの新しい技術を普及させた，特に金型成形品で は材料コストの比率が高いため材料歩留まりの向上はコス 卜削減効果は大きい.

グローバル化が進むなかで, 当初熟練を要する日本の金 型技術は簡単には海外に伝わらないとみられていたが，実 際には IT 化が進んだ高度な輸入生産財が現地で入手でき ることもあり，特別に要求の峳しい金型でない限り現地で 製造できるようになりつつある。この技術移転には外国企 業の現地生産と金型輸出が大いに関係している。これは金 型の 2 大需要分野である自動車と電機産業で中国にて共通 に見られる現象であるが，中国ではすでに巨大設備を有す る金型工場が出現しており，生産規模の面では世界一の日 本の座が脅かされる状況になりつつある。同時に中国製の 量産工業製品が日本にも違和感なく受け入れられつつあ り，金型品質の面でも高いレベルに達しつつある．このこ とは価格的にも海外の金型メーカが強みを発揮し，日本へ の輸出を増加させている.

\section{5. 新製品と新技術開発で生き残る}

金型産業・金型技術は，機械部品製造業の動向に支配さ れる，電子産業に比べれば技術変化は緩やかとはいえ, 求 められる機械部品の機能やコストはますます高度で㛜しく なっている，量産技術もさることながら，新製品には新部 品が開発されることも多く，そのたびに新部品には新しい 金型技術が求められる。新しい金型が既存設備で製造でき たとしても，成形のノウハウまで含めて完成度を上げる に, 熟達した相当レベルの技術者が必要である. 例えば最 近話題のバイオチップ用微細流路, 微細表面をもつ光学素 子, 太陽電池用レンズアレイ, 燃料電池用セパレー夕, 電 気自動車用電池ケースなどいずれも成形品が使われ，その 金型には特殊なものが使われる。そのほか新素材が採用さ れれば，通常は難成形材であり金型も特殊なものの開発が 求められる。つまり日本で高度なものづくりが続く限り, 日本の金型づくりは消えることはない，

さらに新しいものづくり技術となると, 生産設備の改良 や開発が必要であり，このインフラは今のところ世界の中 で日本が断トッで恵まれている。恐らく当分の間，日本の 新技術・新製品開発での優位な地位は維持するものと思わ れる，IT万能のように見える金型作りではあるが，ITを 使いこなすのは人間であり，人間の感性である。とりわけ 新しいものに挑戦する場合は，十分過ぎるほどの細やかな 配慮が求められ，ここに日本人の特性を期待したいところ である。

これからの日本の製造業は，グローバル化を進展させつ つも日本を新製品・新技術開発基地として活用していくの である、日本の金型産業は顧客である機械製造業をサポー トする産業であり，どんなに厳しくとも求めに応じて金型 技術を高めていく道しか残されていないのである. 